\title{
LEPROSY AFTER THE WAR
}

B. Moiser, O.B.E., M.B., M.R.C.S.

We read and hear a great deal about provision for men who have been blinded and maimed in the present War, but no reference to leprosy has been observed.

No figures are available here in connection with the spread of leprosy after the 1914-1S War, but I think that it can be taken as certain that there will be a number of British soldiers who will have become infected with the disease during this war, especially amongst prisoners of war.

Many of the countries involved in the present war are 
highly condemic areas. Cireece and Crete are by no means frec Irom the disease, whilst it is very prevalent in West Africa, and right across to Egypt and the Sudan. liggures of five per thousand are given for large tracts of A frica, e.g., Belgian Congo, the Rhodesias, French Equatorial Africa, Uganda, and almost the whole of the rest of A frica between 20 degrees North and South show one or more per thousand. India, China, Japan and the Netherlands East Indies exhibit a similar degree of endemicity.

The conditions which are favourable for the spread of the disease are war, hot moist climate, poor housing, overcrowding, ignorance of the disease, undernourishment, insanitary conditions and lack of facilities for personal cleanliness. With large numbers of soldiers waging war under such conditions, especially in the lar East, it secms impossible for numbers of them to escape infection from leprosy. I fear that the numbers may be large.

What is to be done for these men? It seems to me that now is the time to make preparations for them. Is Britain a suitable place for them? My answer is in the negative, both from the point of view of the patients themselves, and because of the undesirability of reintroducing the disease into the: British Isles, i.e. from the Public Health point of view.

Fourteen years' experience at Ngomahuru Leprosarium in Southern Rhodesia, near Fort Victoria, a few miles from the renowned Great Zimbabwe Ruins, prompis me to suggest that Ngomahuru is a very suitable place for them. The type of the disease in Southern Rhodesia is a mild one. The climate is very suitable. Remarkably good results from treatment have alreacis been recorded at Ngomahuru, in both white people and in natives.

Ngomahuru is an estate of 8,400 acres of undulating land, interspersed with rocky kopjes, well wooded, with a good water supply, and a marked absence of malaria. Mosquito nets are unnecessary at any time of the year. There is always a breeze. March and October are hot, but the temperature on my verandah has never reached $100^{\circ} \mathrm{F}$. Most of the land still remains to be cultivated. Horses, cattle and sheep thrive well. In short, Ngomahuru is just waiting to be developed, and in my opinion offers the best possible chance of complete recovery from the disease, and a return to normal life later.

This idea of making Ngomahuru into a "British Empire Leprosarium" has been mooted for several years, and indeed it is in existence as such in a small way already, for a few 
Europeans from England, India and Burma have been cured here, or are still undergoing treatment.

Patients would not be herded together in the wards of a large hospital. They would live in separate completely detached, self-contained homes, one man to each house, or perhaps two friends sharing one house. Each man would grow his own vegetable's and flowers, with the help of native servants, and would make the place his "Home" for as long as he remains here. His surroundings should, and would, be made as attractive as possible, and he must have congenial occupation. For instance, one man here at present is in charge of the water supply, which is pumped up from the River Tokwe, and he receives remuneration for this. Another is giving his valued services free as a clerk in the oflice. Plenty of outchor ocenpattion can be found in supervising labour ganges of native patients on the firm, roads, plantations, etc.

Recreation can easily be provicled. A golf course has been in existence for some years, luut was ploughed out for farm crops as a war measure. There are two temnis courts in existence. One man has his own small swimming bath which is filled with chlorinated water, so that it is free from bilharzia. There is a boat on the river, and there are fish to be caught there. Ciuinea fowl, francolin and small game provide sport. The native patients play football with enthusiasm. Cricket is a possibility for Europeans. A reading-room and indoor games present no difficulties. The large "Beit Hall" already in existence is used for religious services.

Under such conditions, nobody could regard himself as a "prisoner." He would have ample liberty to do as he liked, and motor around the countryside. I have always laid stress on the psychological aspect of treatment. Men must not be allowed to feel in any way that they have an "unclean" disease or are in any sense outcasts. One man here has told me that the dlays "fly by," that he has forgotten that he has any disease at all, that he ferls "OF " the place and not "IN" it. That man is getting well rapidly. His wife, who lives in Fort Victoria, comes to visit him at week-ends. His small daughter is allowed. to come occasionally, so long as certain restrictions are observed. Another man (from India), who was cured here, has bouoht a farm in the neighbourhood, married, and settled (lown most happily and successfully.

Then comes the anestion as to whether a man may have his wife to live with him. I have always encouraged this, for conjugal infections are rare. It is rather a matter for the man 
himself to decide after all the facts have been explained to him. One such example has been here for over two years, with the happiest effects. They have made their house and garden most attractive; their rockery, which is a natural one, is always a beautiful sight. 'They have their friends to visit them, but the begetting of children is discouraged, for that would mean the departure of the wife and child, at least temporarily.

Such is the picture I have witnessed here for the past fourteen years, a very different picture from what most people imagine a I eprosarium to be.

So here is the place, and I hope it will become the recognised "British Empire L.eprosarium," where our stricken soldiers can live in comfort and happiness until they return to normal life again.

It is my small part to bring this idea to the notice of the Imperial Government, and of the Colonial Office, and it will be theirs to work out the financial situation, with the Government of Southern Rhodesia. I might here add, in conclusion, that a house with water, indoor water-horne sanitation, and electric light will cost about $£ 700$ to $£ \mathrm{I}, 200$ according to size. 